AL IBTIDA: JURNAL PENDIDIKAN GURU MI (2021) Vol 8 (2): 144-160

DOI: http://dx.doi.org/10.24235/al.ibtida.snj.v8i2.8253

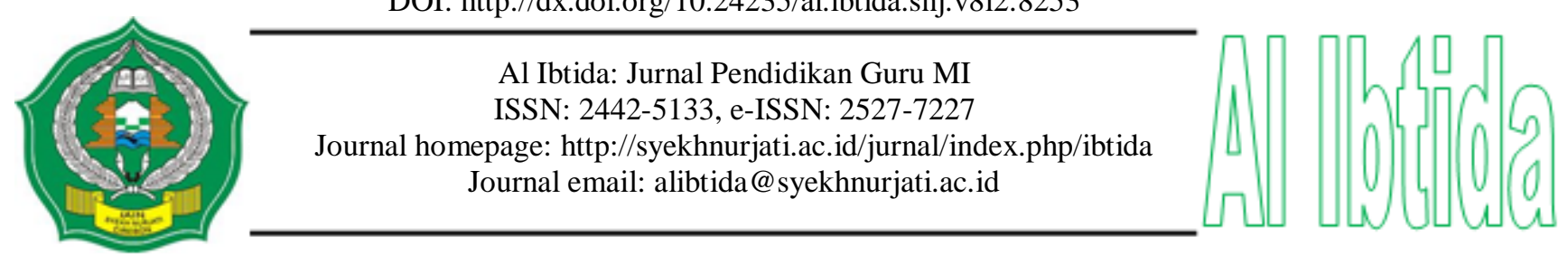

\title{
Development of Web E-Scaffolding Based on Scientific Explanation as Teaching Materials for Primary School Pre-service Teachers
}

\author{
Rizki Amelia* \\ *Department of Madrasah Ibtidaiyah Teacher Education, Faculty of Tarbiyah and Teacher Training, \\ Universitas Islam Negeri Maulana Malik Ibrahim Malang, Indonesia. \\ Email: rizkiamelia@uin-malang.ac.id
}

Received: April 18 ${ }^{\text {th }}, 2021$. Accepted: October 19 ${ }^{\text {th }}, 2021$. Published: October $30^{\text {th }}, 2021$.

\begin{abstract}
Science learning does not only involve facts and concepts but also ways of thinking, explaining scientifically, and doing a practicum. Unfortunately, existing e-learning and/or social media have not been able to facilitate the implementation of online practicums. Therefore, an e-scaffolding website based on scientific explanations is needed as teaching media and materials since learning is mostly conducted online during the Covid-19 pandemic. This study aims to describe the development process and the validity and legibility of the e-scaffolding website to develop scientific explanations for elementary school pre-service teachers. The development of this escaffolding website refers to the development model developed by Lee and Owens (2004). The instrument of this study was a questionnaire using a Likert scale. There are 3 kinds of questionnaires used, including the material validation questionnaire by the expert validator, the media validation questionnaire by the expert validator, and the student readability test questionnaire. The results showed that the average product validation results on the website aspect were $84 \%$ and, on the e,-scaffolding aspect was $86.67 \%$. While the results of the product readability test were $82.29 \%$. This means that the development of the e-scaffolding website based on scientific explanations is very valid and very feasible to use in developing the scientific explanation abilities of elementary school pre-service teachers
\end{abstract}

Keywords: website e-scaffolding, scientific explanation, teaching materials.

\begin{abstract}
Abstrak
Dalam pembelajaran sains tidak hanya melibatkan fakta dan konsep, tetapi juga cara berpikir dan menjelaskan secara ilmiah. Selain itu, dalam pembelajaran sains juga membutuhkan praktikum. Sayangnya, e-learning atau media sosial yang ada belum dapat memfasilitasi pelaksanaan praktikum online. Oleh karena itu, dibutuhkan website e-scaffolding berbasis penjelasan ilmiah sebagai media dan bahan ajar di masa pandemi Covid-19. Penelitian ini bertujuan untuk mendeskripsikan proses pengembangan dan kevalidan serta keterbacaan website e-scaffolding untuk mengembangkan scientific explanation calon guru sekolah dasar. Pengembangan website e-scaffolding ini mengacu pada model pengembangan yang dikembangkan oleh Lee \& Owens. Instrumen pengumpulan data berupa angket dengan menggunakan skala likert. Angket yang digunakan ada 3 macam, yaitu angket validasi materi oleh validator, angket validasi media oleh validator, dan angket uji keterbacaan siswa. Hasil penelitian
\end{abstract}


menunjukkan bahwa rata-rata hasil validasi produk pada aspek website sebesar $84 \%$ dan pada aspek e-scaffolding sebesar $86,67 \%$. Sedangkan hasil uji keterbacaan produk sebesar $82,29 \%$. Hal ini berarti bahwa pengembangan website e-scaffolding berbasis penjelasan ilmiah sangat valid dan sangat layak digunakan dalam mengembangkan kemampuan penjelasan ilmiah calon guru sekolah dasar.

Kata kunci: website e-scaffolding, penjelasan ilmiah, bahan ajar.

\section{INTRODUCTION}

In the mid of March 2020, all educational institutions in Indonesia changed their technical learning into online learning, to reduce the impact of COVID-19. The closure of educational institutions has also occurred in dozens of countries due to the COVID-19 pandemic (Purwanto et al., 2020). UNESCO estimates that nearly 900 million students have experienced the closure of educational institutions due to the COVID-19 pandemic (Nicola et al., 2020).

The closure of educational institutions ranging from pre-school education, basic education, and the tertiary level due to the COVID-19 pandemic has greatly affected the learning process and educational curriculum (Rahmawati \& Putri, 2020). The learning process in the classroom must be converted into learning from home or school for home methods (Herliandry et al., 2020). The government's decision to close all educational activities makes the government and related educational institutions have to provide alternatives and innovations in the educational process for students who are undertaking school from home (Purwanto et al., 2020). The learning innovation impact of COVID-19 opens a new paradigm for educational institutions that no longer require the learning process to be face-to-face in class (Fitriyani et al., 2020). There is an important role of online distance information technology system in education that must be prepared to undertake school from home.

Online learning occurs all over the world during the COVID-19 pandemic (Goldschmidt, 2020). At the higher education level, the lecturers initially carried out blended learning (Garrison \& Vaughan, 2008; Porter et al., 2014; Wintarti et al., 2019), and finally, they should move to use e-learning. This sudden change requires adaptation, so most lecturers use relatively easy online applications such as Google Classroom (Octaberlina \& Muslimin, 2020; Tinungki \& Nurwahyu, 2020), Moodle (Dascalu et al., 2021; Hanafie Das et al., 2020; Wicaksana, 2020), and Edmodo (Sefriani et al., 2021; Wicaksana et al., 2020). Some others also use social media, such as Whatsapp, Telegram, Youtube, Zoom, Cisco Webex, etc (Budianto \& Arifani, 2021; Haqien \& Rahman, 2020; Serhan, 2020; Susilawati \& Supriyatno, 2020). 
One of the areas affected by the COVID-19 pandemic is science. Science learning does not only involve facts and concepts but also scientific ways of thinking and explaining (Amelia, 2021; Amelia et al., 2020). Science consists of facts, concepts, and principles and requires explanations of contextual problems using problem statements, relating facts to concepts, and explaining problems scientifically called a scientific explanation (McNeill, 2011). The scientific explanation is a very important ability for prospective teachers. Thus, learning that can encourage students' scientific explanations is necessary.

In addition to explaining facts, principles, and concepts, learning science also requires a practicum. One of the difficulties in implementing online science learning in the Covid-19 era is the inability to carry out online practicum (Ambawati et al., 2021). Moreover, e-learning or social media cannot facilitate the implementation of online practicum. This is because of the limitations of e-learning that only provides discussion forums, assignments submission, learning material content, and quizzes. One of the online media that could potentially facilitate online science practicum is the e-scaffolding website.

Scaffolding is a technique for changing the level of support during the learning process, provided by a more competent teacher or classmate, adjusting the support provided to student performance (Santrock, 2011). Scaffolding involves the process of observing students' zone proximal development (ZPD) and prioritizing priorities in determining the learning process (Hughes, 2009). Scaffolding has been developed in the various learning contexts with different students to achieve different goals and in different environments, such as language learning (Mirahmadi \& Alavi, 2016), science classes, and mathematics (Amiripour et al., 2012).

Scaffoldings used in science classes have some benefits. The benefit of using scaffolds is to provide support to achieve learning objectives that include attitudes, processes, and physical content (Podolefsky \& Finkelstein, 2007). Custom scaffolds for physics through elearning can improve student performance and motivation (Chen, 2014). In the cognitive domain, scaffolding increases the effectiveness of students' use of abstract representations (Podolefsky \& Finkelstein, 2007). A stronger and more integrated knowledge organizational structure is a useful skill for solving physical problems.

Compared to the previous research, the scaffolding that will be developed in this study is an online web-based scaffolding. The online web was chosen because technology has many features that can be used in learning and can provide benefits for both teachers, students, and the community (Frei et al., 2006). By utilizing technology, teachers can increase the effectiveness and efficiency of learning. For students, the use of technology can provide better quality learning opportunities. In general, the use of technology also benefits society at large 
because people can obtain various information that is easily obtained and disseminated by the community (Martin \& Ertzberger, 2013). The use of the computer allows learning time to be more effective than learning time in class. The positive attitude of students also appears in the use of computer media in learning, and the development of computer-based learning can be easily adapted to be applied in several places and contexts.

The results of research by Ding \& Zhang (2018) show that web-based teaching and learning can make it easier for students. Learning that uses a combination of face-to-face and online web-based learning is proven to be more effective in improving cognitive learning outcomes (Barisone et al., 2019). Online learning in this study was carried out using an online web with online scaffolding facilities called e-scaffolding. Based on several thoughts that have been described by the researcher, this study aims to produce an e-scaffolding model to improve the quality of the process and cognitive learning outcomes of students and time flexibility.

The difference between this study and previous research is that this study uses Phet integration as a virtual practicum and synchronizes answers and student activities directly to the admin account. E-scaffolding in this study is applied in online web learning and used virtual practicum with Phet. This e-scaffolding can be used as student self-study material. In the implementation, students use e-scaffolding as independent study material and a system to carry out virtual practicum. Materials or practicums that have not been understood by students are discussed in online lectures with videoconferences. Thus, a high level of achievement and quality of learning in the classroom will be obtained. E-scaffolding websites can improve the quality of learning (Ayu et al., 2017), understanding the concept (Amelia et al., 2016; Jufriadi et al., 2019), scientific attitude (Affriyenni, 2014), problem-solving skills (Setiawan, 2018), and scientific explanation (Amelia, 2021; Amelia et al., 2020).

This research is deemed necessary because so far there has been no application of webbased e-scaffolding that has been integrated with Phet. Several previous studies used escaffolding based on e-learning Moodle (Amelia et al., 2020; Ayu et al., 2017; Koes-H et al., 2019). In addition, the research of Oktavianti et al., (2018) uses e-scaffolding based on blended learning. The use of e-scaffolding allows students to have the freedom to develop their ability to understand and solve scientific problems. Online web-based learning provides opportunities for students to use their time more freely in studying material (Coomey \& Stephenson, 2018; Mukhtar et al., 2020). Therefore, a scientific explanation-based e-scaffolding website is needed as teaching material during the Covid-19 pandemic. 


\section{METHODS}

This development of e-scaffolding website media refers to the development model developed by (Lee \& Owens, 2004). The researcher chooses Lee and Owens ' development model because it is compatible with multimedia-based development. This development model has five stages as shown in Figure 1. The research and development that is carried out are limited to only the first three stages, namely assessment/analysis, design, development only. The implementation and evaluation stages were not carried out due to the limited time, efforts, and costs of the researchers.

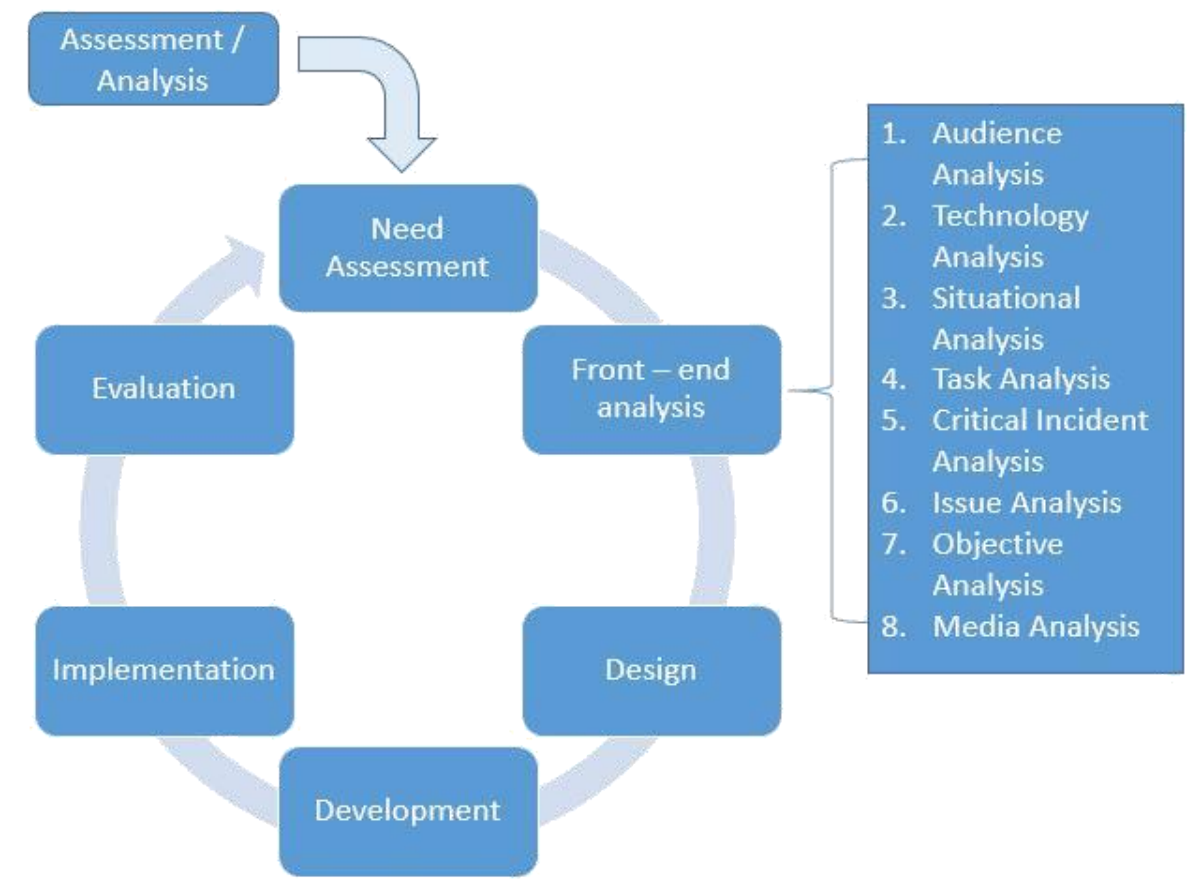

Figure 1. Lee and Owens' Research and Development Model Chart

The stages of product testing are divided into five, namely trial design, trial subjects, types of data, data collection instruments, and data analysis techniques. The trials carried out on the development of the e-scaffolding website consist of validation tests and legibility tests. The validation test consists of two parts, namely material validation and media validation. Material and media validation aims to determine the feasibility of the media being developed. The legibility test was carried out on Madrasah Ibtidaiyah Teacher Education (PGMI) students of State Islamic University (UIN) of Maulana Malik Ibrahim Malang with a specialization in science to find out the understanding and ease of students in using the developed learning media. Validation and legibility tests were carried out by providing a questionnaire containing an assessment column and a column for comments and suggestions. The subject of the material and media validation test of the developed teaching materials. The criteria for each validator are a lecturer, with the qualification of a science lecturer, having completed a minimum master 
degree (S2), mastering and understanding the aspects of the study. The legibility test that was carried out involved students of PGMI UIN Maulana Malik Ibrahim Malang semester VI.

This research and development use questionnaire using a Likert scale with a score of 15. There are 3 kinds of questionnaires used, namely the material validation questionnaire by the validator, the media validation questionnaire by the validator, and the readability test questionnaire by the students. Data quantitative obtained from the validation and legibility test results then analyzed based on the percentage calculation. After data analysis was conducted, the criteria for interpretation of the average analysis score were carried out to determine the validity of the developed teaching materials, as seen in Table 1 below.

Table 1. Mean Analysis of Score Interpretation Criteria

\begin{tabular}{cc}
\hline Percentage (\%) & Criteria \\
\hline $0-20$ & Very weak/unworthy / invalid \\
\hline $21-40$ & Weak / Inadequate / less valid \\
\hline $41-60$ & Enough / Fairly Feasible / Sufficiently Valid \\
\hline $61-80$ & Strong / Feasible / Valid \\
\hline $81-100$ & Very Strong / Very Worthy / Very Valid \\
\hline
\end{tabular}

Source: (Setyosari, 2016)

\section{RESULTS AND DISCUSSION}

\section{Description of Development Results}

In the introduction, there is a login page and dashboard page. The login page is the initial page that appears when we first open the Sainsasyik.com web. On the login page, if the user already has an account, the user can click login and enter the username and password that was created. However, if the user does not have an account on this website, then the user can click the registration menu and enter the full name, email, username, and password that they want. The display of the login page and register page can be seen in Figure 2. After the user logs in, the user will be directed to the dashboard page. This dashboard page contains what menu materials are available on this website. Currently, on this website, there is a menu of Newtonstyle and Law materials. So that the user can choose what material he/she will learn. The dashboard page display can be seen in Figure 3. 


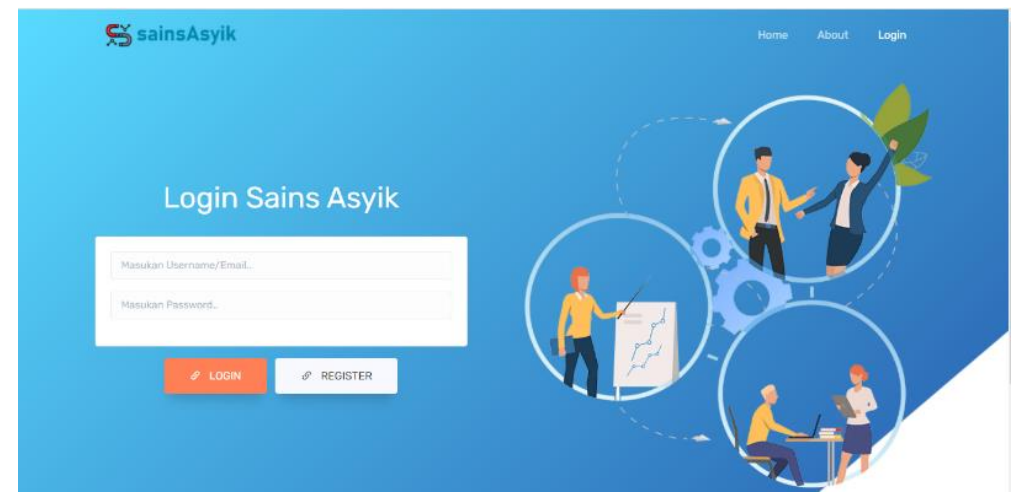

Figure 2. Display of the Login Page

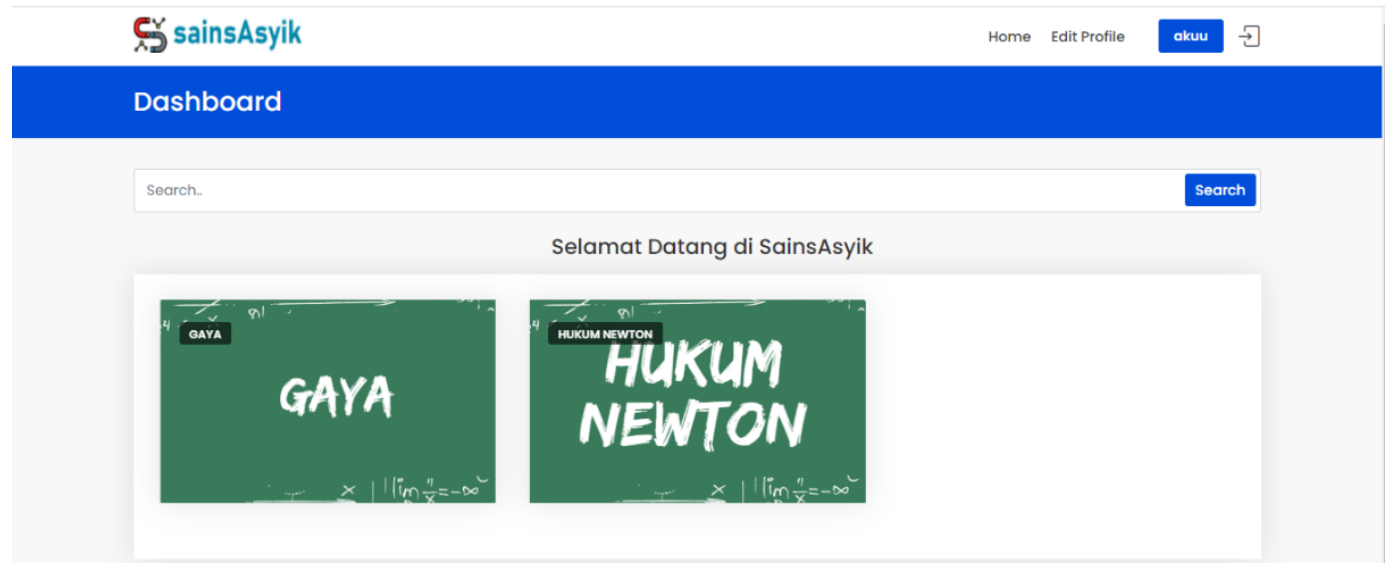

Figure 3. Dashboard Page Views

When the user selects one of the materials on the dashboard menu, the user will be directed to the start page of the material which shows a description of the learning objectives of the material, keywords, and applications in elementary school learning. Applications in elementary school learning intend that students understand this material to be studied in what class in elementary school. The initial page display of the material can be seen in Figure 4. The main menu on this website is a worksheet. On the worksheet, several points can guide students in carrying out practicum virtually, including practicum objectives, practicum implementation procedures, and practicum results. This worksheet menu is also directly integrated with Phet, making it easier for students to do practicum virtually with this website. The Phet display on the worksheet menu can be seen in Figure 5. After students carry out the practicum, then students can enter the practicum result data into the practicum results menu. Student answers on the practicum results menu go directly to the admin menu so that the admin/lecturer can assess the results of student work. The experimental results menu display can be seen in Figure 6. 


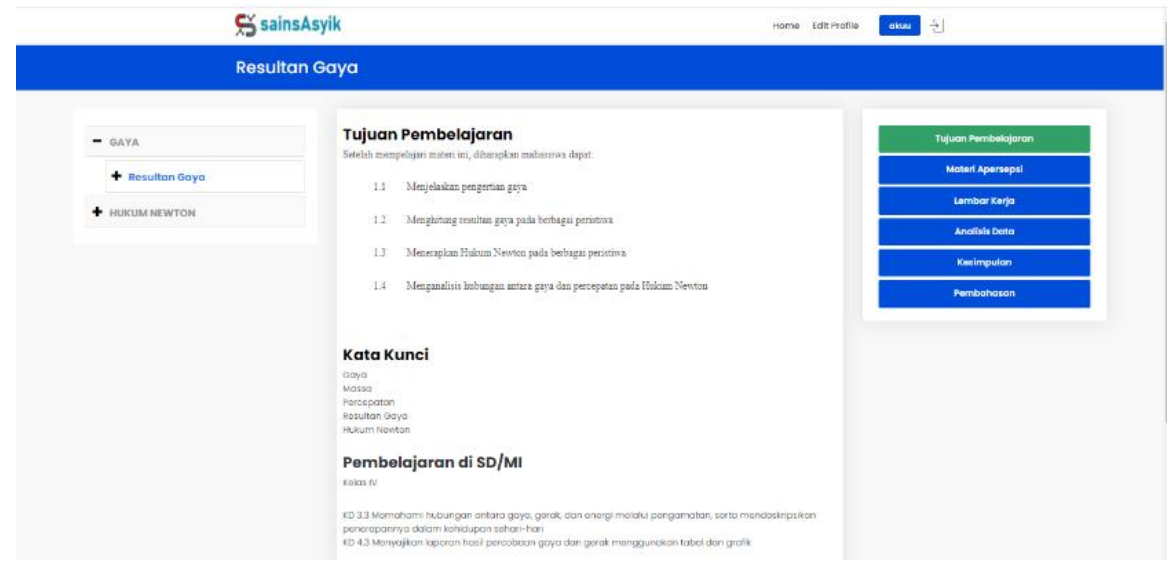

Figure 4. Material Start Page

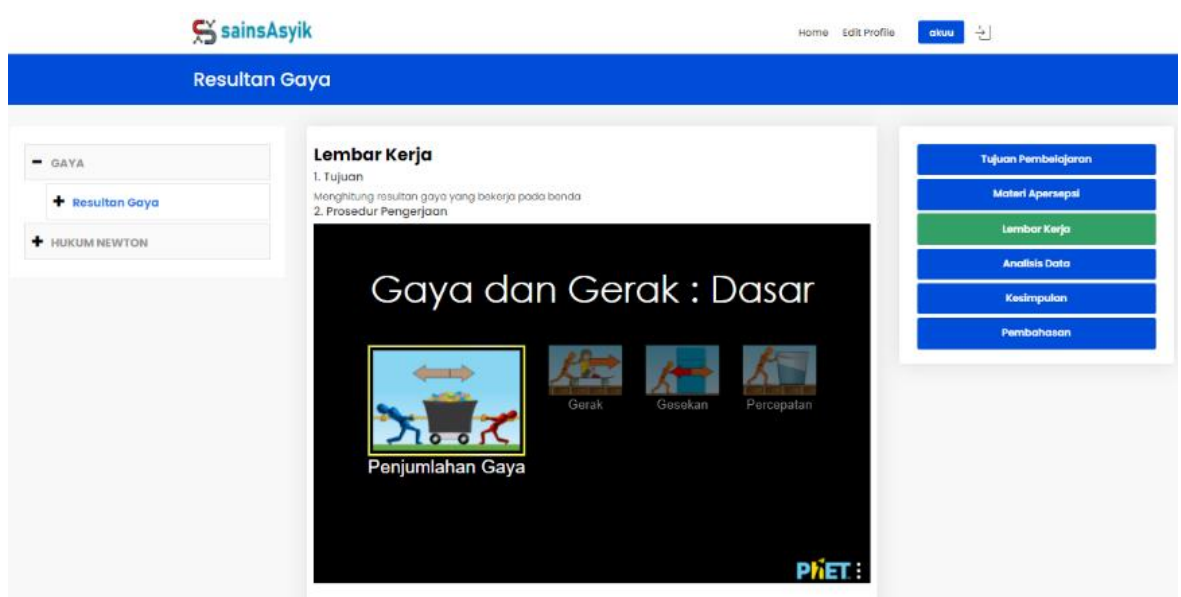

Figure 5. Pages of the Integrated Phet Worksheet

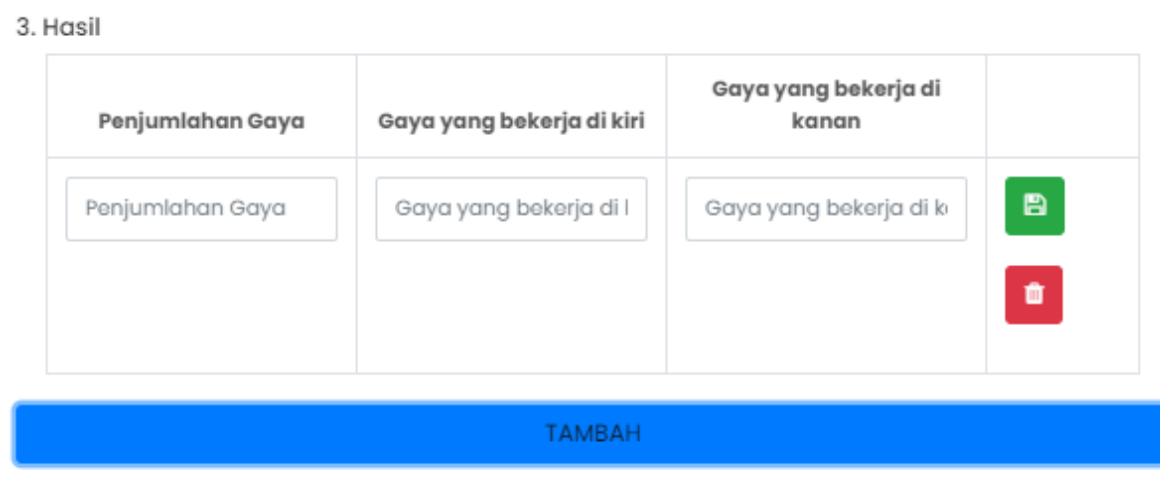

Figure 6. Practicum Results Page

After students have finished carrying out the practicum, students are directed to analyze the data from the practicum results. In the data analysis menu, there is a column to explain the results of the experimental data analysis. Data analysis on this website is directed at three scientific explanation indicators, namely claim, evidence, and reasoning. In addition, on the data analysis menu, there is also a scaffolding in the form of a help menu, which can be clicked whenever students need it. The recorded data on the number of times a student clicks on the 
help menu is also recorded in the admin/lecturer data. The data analysis menu display and its scaffolding can be seen in Figure 7. The help menu display can be seen in Figure 8. After students have finished compiling data analysis consisting of claims, evidence, and reasoning, then students are directed to make conclusions. The answers that students type in making conclusions are also recorded on the admin/lecturer account. So that lecturers can assess student performance. In this conclusion menu, there is still scaffolding in the form of a help menu. Scaffolding in this conclusion menu directs students to make conclusions by adjusting the practicum objectives described earlier. The conclusion menu display can be seen in Figure 9.

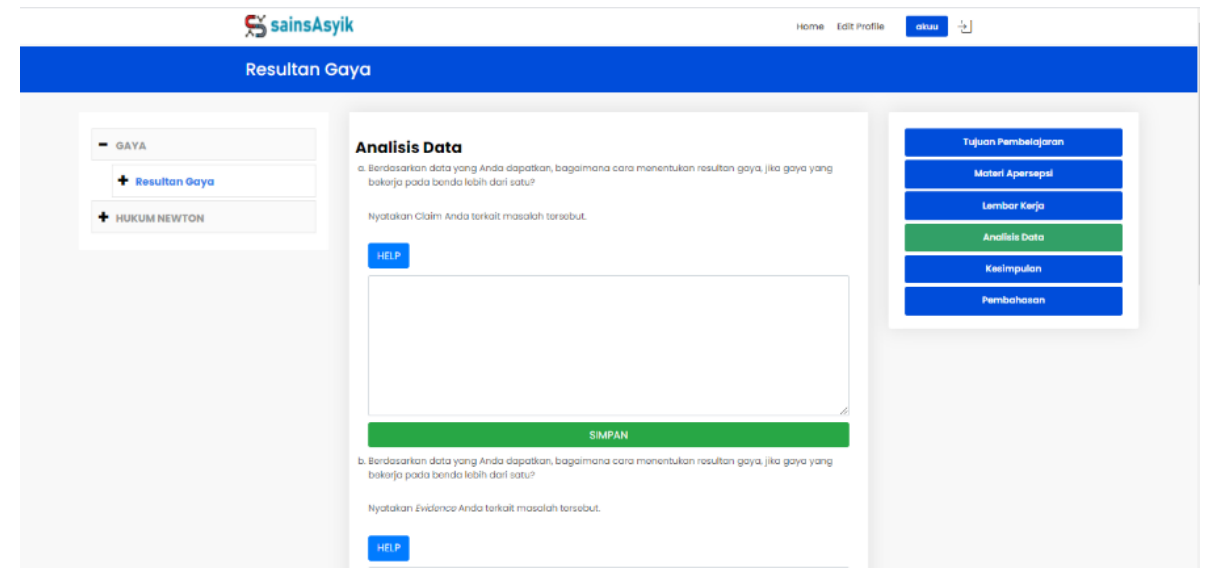

Figure 7. Data Analysis Menu

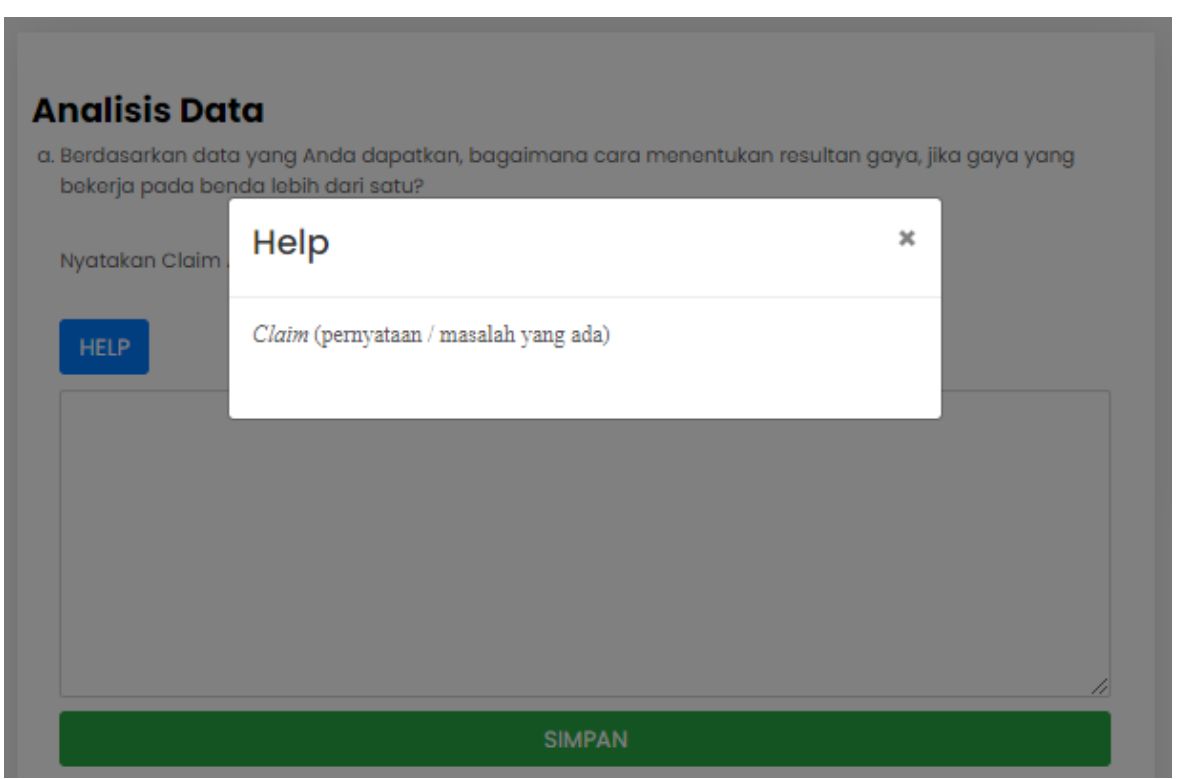

Figure 8. Menu Help (Scaffolding) 


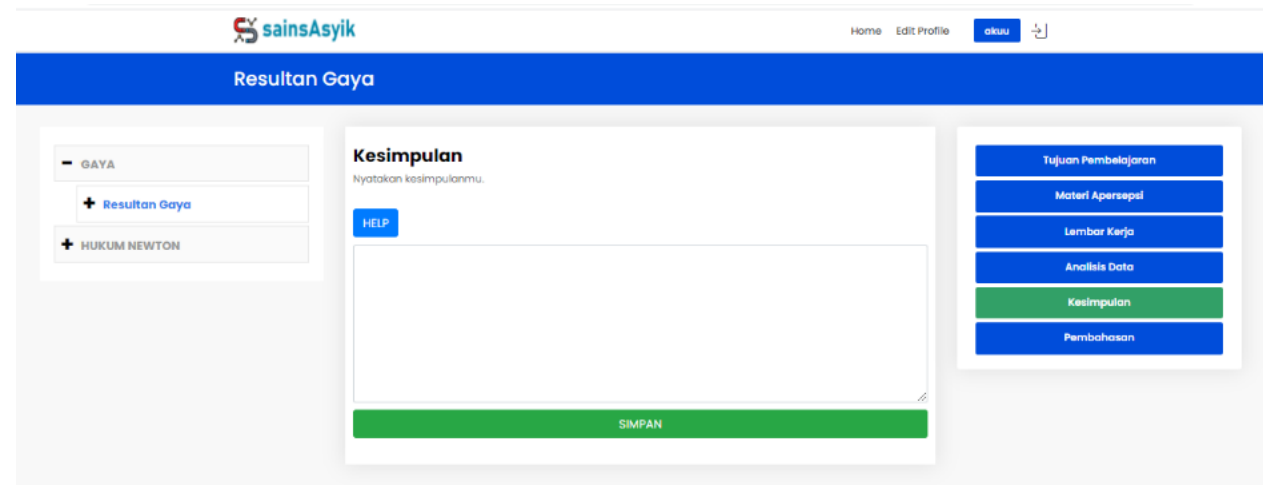

Figure 9. Conclusion Menu

\section{Analysis of the Validation Results and Readability Test of the E-Scaffolding Website}

The validation of the e-scaffolding sainsasyik.com website was held in July 2020 by three physics lecturers at various universities. The legibility test was carried out in August 2020 involving 27 students of Madrasah Ibtidaiyah Teacher Education who took science concentrations. The data from the validation and legibility tests were obtained from questionnaires in the form of qualitative data and quantitative data. Qualitative data in the form of suggestions and comments obtained from validators and students. The quantitative data obtained is the average score of the questionnaire according to the Likert scale score of 1-5. Furthermore, the data from the questionnaire were analyzed descriptively by the percentage of the score per question item. The results of quantitative data analysis show the feasibility and readability of the e-scaffolding website.

The material validation aspects on the e-scaffolding website consist of material coverage, material accuracy, learning material, and language use. In each aspect of the material, validation results obtained a percentage score of $86.67 \%, 95.55 \%, 89.17 \%$, and $90 \%$. Thus, the material aspect of the e-scaffolding website is very valid. The results of the validation of the escaffolding website material can be seen in Figure 10. In media validation, there are two aspects, namely the website aspect and the e-scaffolding aspect. On the website aspect, the percentage score of the validity of the e-scaffolding website is $84 \%$ which is classified as very valid. Whereas in the e-scaffolding aspect, the percentage score of the validity of the escaffolding website is $86.67 \%$ which is classified as very valid. 


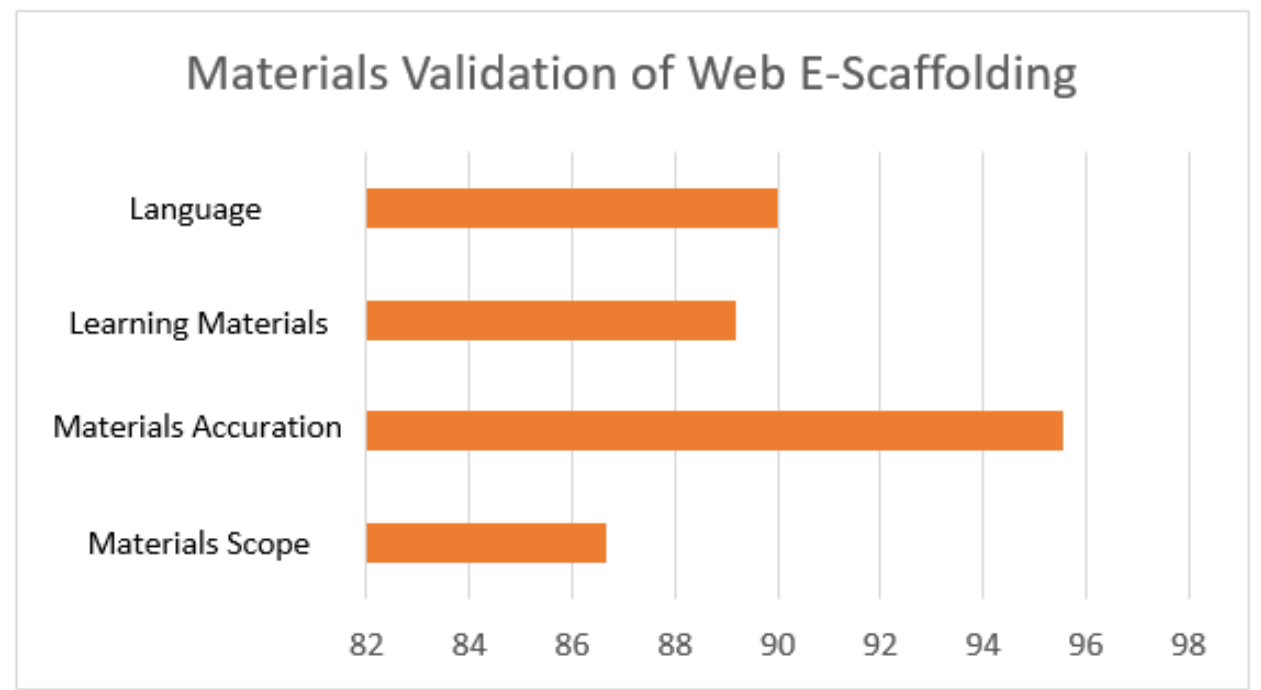

Figure 10. Material Validation Results

The second validation is media validation. In media validation, there are two aspects, namely the website aspect and the e-scaffolding aspect. First, on the website aspect, there are several indicators, including the clarity of navigation in the application, the level of clarity of the instructions for each activity, the level of attractiveness of the facilities in the application, the completeness of the features presented, the appropriateness of the use of icons, and the attractiveness of the design in each presentation. Theory. The results of media validation on the website aspect can be seen in Table 2 . With an average score of $84 \%$ validity percentage, the product website aspect of the e-scaffolding website is declared very valid.

Table 2. Media Validation Results for Website Aspects

\begin{tabular}{llll}
\hline No. & \multicolumn{1}{c}{ Rated Aspect } & $\begin{array}{c}\text { Percentage } \\
\text { of Validity }\end{array}$ & Criteria \\
\hline 1. & $\begin{array}{l}\text { The clarity of the navigation in the } \\
\text { application }\end{array}$ & $86.67 \%$ & Very Valid \\
2. $\quad \begin{array}{l}\text { Level of Clarity of Instructions for } \\
\text { Each Activity }\end{array}$ & $86.67 \%$ & Very Valid \\
3. $\quad \begin{array}{l}\text { The level of attractiveness of the } \\
\text { facilities in the application } \\
\text { The completeness of the features } \\
\text { presented in the application to support } \\
\text { learning objectives } \\
\text { The suitability of using icons and } \\
\text { images with the sentences being } \\
\text { conveyed } \\
\text { The attractiveness of the design in } \\
\text { each material presentation }\end{array}$ & $80 \%$ & Valid \\
5. & $86.67 \%$ & Very Valid \\
& Average & $84 \%$ & Very Valid \\
\hline
\end{tabular}


The second aspect of media validation is the e-scaffolding aspect. In this e-scaffolding aspect, there are several indicators, including the ability of the application to support concept discovery in students, the accuracy of website design to support scientific explanations, the suitability of learning activities in developing scientific explanations, and material content that is suitable and better presented in web form than other media. The results of the media expert's validation on the e-scaffolding aspect can be seen in Table 3 . The average percentage of validity is $86.67 \%$, indicating that the e-scaffolding website is very feasible in the e-scaffolding aspect.

Table 3. Media Validation Results for E-Scaffolding Aspects

\begin{tabular}{clcc}
\hline No. & \multicolumn{1}{c}{ Rated aspect } & $\begin{array}{c}\text { Percentage of } \\
\text { Validity }\end{array}$ & Criteria \\
\hline 1. & $\begin{array}{l}\text { Application capabilities in } \\
\text { supporting concept discovery in } \\
\text { learners }\end{array}$ & $86.67 \%$ & Very Valid \\
2. $\quad \begin{array}{l}\text { Website design accuracy to support } \\
\text { a scientific explanation } \\
\text { the suitability of learning activities } \\
\text { in developing a scientific } \\
\text { explanation } \\
\text { material content is appropriate and } \\
\text { better presented in web form than } \\
\text { any other medium }\end{array}$ & $80 \%$ & Valid \\
\multicolumn{1}{c}{ Average } & $93.3 \%$ & Very Valid \\
\hline
\end{tabular}

Based on the quantitative data description of the results of the validation of the escaffolding website that was developed in each aspect of the assessment, it is known that the average percentage of the feasibility of the material and media is $90.34 \%$ and $85.56 \%$, respectively, with very valid criteria used in the learning process.

This readability test aims to determine the ability of students to understand the contents of the e-scaffolding website so that it is known whether the website is suitable for use in the learning process or not. This legibility test was carried out on PGMI students. The qualitative data obtained shows that most students are very interested in the developed e-scaffolding website because it is presented interactively and is equipped with virtual experiments. The next data obtained is in the form of quantitative data as an assessment of students, and qualitative data in the form of suggestions and comments from students on the e-scaffolding website. The average score of the readability test can be seen in Table 4 . 
Table 4. Validation Results of the Readability Test

\begin{tabular}{llll}
\hline No. & Rated aspect & $\begin{array}{l}\text { Percentage of } \\
\text { Validity }\end{array}$ & Criteria \\
\hline 1. & Website Design & $83.21 \%$ & Very Valid \\
2. & $\begin{array}{l}\text { The Role of the Website in } \\
\text { Supporting Independent }\end{array}$ & $82.59 \%$ & Very Valid \\
& $\begin{array}{l}\text { Learning } \\
\text { Role of Website in Developing } \\
\text { Scientific Explanation }\end{array}$ & $81 \%$ & Very Valid \\
& Average & $82.29 \%$ & Very Valid \\
\hline
\end{tabular}

Based on the descriptions of quantitative data, the validation results of the readability test of the e-scaffolding website that was developed show that the average percentage of the validity of the e-scaffolding website is $82.29 \%$. Thus, the e-scaffolding website developed is very suitable for use in the teaching and learning process and very feasible for developing student scientific explanations.

In general, this e-scaffolding website has advantages and disadvantages. The advantages of this website lie in 1) Virtual practicum, 2) Value and answers that are directly integrated with the admin account, 3 ) the help (scaffolding) feature can be displayed as needed and recorded on the admin account. While the shortcomings of this e-scaffolding website are that virtual loading takes a long time because the Phet integration on the website causes this website to tend to be heavy. However, this can be overcome by preparing an adequate internet network, so that the loading will not take too long.

E-scaffolding in online learning has a positive impact on students' scientific explanation abilities. In independent learning, e-scaffolding provides an excellent means for students to be fully involved in collaborative activities (Amelia \& Mulyoto, 2020), so that students are accustomed to explaining problems scientifically (Amelia, 2021; Amelia et al., 2020; Oktavianti et al., 2018). An increase in scientific explanation ability and scientific attitude occurred in students with moderate and low achievement who obtained significant benefits in online learning. The results Jan et al., (2012) also showed that the use of assistance from multimedia implementation resulted in better performance, and significantly boosted knowledge acquisition.

Virtual practicum with phet helps students understand the concept of the experiment being carried out. This helps students understand theory in science courses. Online learning using e-scaffolding is very suitable for practicum-based courses (Hodges et al., 2018; Keddi \& Frerich, 2020; Makhrus et al., 2021). The use of virtual practicum with phet accompanied by e-scaffolding is expected to facilitate student scientific explanation. 
The difference between this study and previous research is that this study uses phet integration as a virtual practicum and synchronizes answers and student activities directly to the admin account. Several studies on e-scaffolding have been done before. E-scaffolding has been proven to increase scientific explanation (Oktavianti et al., 2018), critical thinking skills, science process skills (Dasilva et al., 2019), problem-solving skills (Saputri \& Wilujeng, 2017), and student learning outcomes (Ayu et al., 2017).

\section{CONCLUSION}

The product of the e-scaffolding website proved to be very valid and legible in developing the scientific explanation of primary school pre-service teachers. However, this research is limited to two streams: Newton style and Law material. Therefore, further research is suggested to develop this e-scaffolding website on other science materials. This e-scaffolding website is expected to be used by various science lecturers for students of elementary school teacher education.

\section{ACKNOWLEDGEMENTS}

The researchers would like to thank the Directorate of Islamic Higher Education, Ministry of Religion Affairs of the Republic Indonesia, and Universitas Negeri Maulana Malik Ibrahim Malang for funding this research in the scheme of Litapdimas Clusters of Research Development/Capacity Building Continuation in 2021.

\section{REFERENCES}

Affriyenni, Y. (2014). Pengembangan e-scaffolding termodinamika berbasis pembelajaran hybrid untuk menumbuhkan sikap ilmiah dan prestasi belajar fisika. Universitas Negeri Malang.

Ambawati, R., Putri, E. K., Rahayu, D. A., \& Khaleyla, F. (2021). Science online learning during the covid-19 pandemic: Difficulties and challenges. Journal of Physics: Conference Series, 1747(1), 012007.

Amelia, R. (2021). The influence of e-scaffolding in blended learning on prospective teacher's scientific explanation. Journal of Physics: Conference Series, 1796(1), 012039.

Amelia, R., Handayanto, S. K., \& Muhardjito, M. (2016). The Influence of V Diagram Procedural Scaffolding in Group Investigation Towards Students with High and Low Prior Knowledge. Jurnal Pendidikan IPA Indonesia, 5(1), 108-115.

Amelia, R., \& Mulyoto, G. P. (2020). Hybrid Active Learning to Develop the Science Competence of Preservice Elementary Schools Teachers.

Amelia, R., Rofiki, I., Tortop, H. S., \& Abah, J. A. (2020). Pre-service teachers' scientific explanation with e-scaffolding in blended learning. Jurnal Ilmiah Pendidikan Fisika Al Biruni, 9(1), 33-40. 
Amiripour, P., Amir-Mofidi, S., \& Shahvarani, A. (2012). Scaffolding as effective method for mathematical learning. Indian Journal of Science and Technology, 5(9), 3328-3331.

Ayu, H. D., Pratiwi, H. Y., Kusairi, S., \& Muhardjito, M. (2017). Developing E-Scaffolding To Improve The Quality Of Process And Learning Outcomes. Jurnal Kependidikan: Penelitian Inovasi Pembelajaran, 1(2), 334-347.

Barisone, M., Bagnasco, A., Aleo, G., Catania, G., Bona, M., Scaglia, S. G., Zanini, M., Timmins, F., \& Sasso, L. (2019). The effectiveness of web-based learning in supporting the development of nursing students' practical skills during clinical placements: A qualitative study. Nurse Education in Practice, 37, 56-61.

Budianto, L., \& Arifani, Y. (2021). Utilizing WhatsApp-driven learning during the covid-19 outbreak: Efl users' perceptions and practices. Call-Ej, 22(1), 264-281.

Chen, C.-H. (2014). An adaptive scaffolding e-learning system for middle school students' physics learning. Australasian Journal of Educational Technology, 30(3).

Coomey, M., \& Stephenson, J. (2018). Online learning: It is all about dialogue, involvement, support and control-According to the research. In Teaching \& learning online (pp. 3752). Routledge.

Dascalu, M.-D., Ruseti, S., Dascalu, M., McNamara, D. S., Carabas, M., Rebedea, T., \& Trausan-Matu, S. (2021). Before and during COVID-19: A Cohesion Network Analysis of Students' Online Participation in Moodle Courses. Computers in Human Behavior, 106780.

Dasilva, B. E., Ardiyati, T. K., Suparno, S., Sukardiyono, S., Eveline, E., Utami, T., \& Ferty, Z. N. (2019). Development of Android-Based Interactive Physics Mobile Learning Media (IPMLM) with Scaffolding Learning Approach to Improve HOTS of high school students in Indonesia. Journal for the Education of Gifted Young Scientists, 7(3), 659681.

Ding, Y., \& Zhang, P. (2018). Practice and effectiveness of web-based problem-based learning approach in a large class-size system: A comparative study. Nurse Education in Practice, 31, 161-164.

Fitriyani, Y., Fauzi, I., \& Sari, M. Z. (2020). Motivasi belajar mahasiswa pada pembelajaran daring selama pandemik covid-19. Jurnal Kependidikan: Jurnal Hasil Penelitian dan Kajian Kepustakaan di Bidang Pendidikan, Pengajaran dan Pembelajaran, 6(2), 165175.

Frei, S., Gammill, A., \& Irons, S. (2006). Integrating Technology into the Curriculum: All Grades. Teacher Created Materials.

Garrison, D. R., \& Vaughan, N. D. (2008). Blended learning in higher education: Framework, principles, and guidelines. John Wiley \& Sons.

Goldschmidt, K. (2020). The COVID-19 pandemic: Technology use to support the wellbeing of children. Journal of Pediatric Nursing, 53, 88.

Hanafie Das, S. W., Halik, A., Iman, B., Tahir, M., Hamid, E., Djollong, A. F., \& Kenre, I. (2020). Developing a Sociocultural Approach in Learning Management System through Moodle in the Era of the Covid-19. International Journal of Innovation, Creativity and Change, 13(27), 941-958.

Haqien, D., \& Rahman, A. A. (2020). Pemanfaatan Zoom Meeting Untuk Proses Pembelajaran Pada Masa Pandemi Covid-19. SAP (Susunan Artikel Pendidikan), 5(1). 
Herliandry, L. D., Nurhasanah, N., Suban, M. E., \& Kuswanto, H. (2020). Pembelajaran pada masa pandemi covid-19. JTP-Jurnal Teknologi Pendidikan, 22(1), 65-70.

Hodges, G. W., Wang, L., Lee, J., Cohen, A., \& Jang, Y. (2018). An exploratory study of blending the virtual world and the laboratory experience in secondary chemistry classrooms. Computers \& Education, 122, 179-193.

Hughes, F. P. (2009). Children, play, and development. Sage.

Jan, L. G., de Kruif, A., \& Valcke, M. (2012). Differential impact of unguided versus guided use of a multimedia introduction to equine obstetrics in veterinary education. Computers \& Education, 58(4), 1076-1084.

Jufriadi, A., Ayu, H. D., \& Pratiw, H. Y. (2019). Developing E-Scaffolding Integrated with EAssessment to Improve Student's Mastery of Concept. 1st International Conference on Education and Social Science Research (ICESRE 2018), 176-179.

Keddi, D., \& Frerich, S. (2020). Enhancing Engineering Education by Virtual Laboratories. International Conference on Remote Engineering and Virtual Instrumentation, 359365.

Koes-H, S., Suwasono, P., \& Pramono, N. A. (2019). Efforts to improve problem solving abilities in physics through e-scaffolding in hybrid learning. AIP Conference Proceedings, 2081(1), 030006.

Lee, W. W., \& Owens, D. L. (2004). Multimedia-based instructional design: Computer-based training, web-based training, distance broadcast training, performance-based solutions. John Wiley \& Sons.

Makhrus, M., Wahyudi, W., \& Zuhdi, M. (2021). Students' conceptual understanding through implementation of livewire in basic electronics virtual experiment. Jurnal Penelitian Pendidikan IPA, 7(2), 249-254.

Martin, F., \& Ertzberger, J. (2013). Here and now mobile learning: An experimental study on the use of mobile technology. Computers \& Education, 68, 76-85.

McNeill, K. L. (2011). Elementary students' views of explanation, argumentation, and evidence, and their abilities to construct arguments over the school year. Journal of Research in Science Teaching, 48(7), 793-823.

Mirahmadi, S. H., \& Alavi, S. M. (2016). The role of traditional and virtual scaffolding in developing speaking ability of Iranian EFL learners. International Journal of English Linguistics, 6(2), 43-56.

Mukhtar, K., Javed, K., Arooj, M., \& Sethi, A. (2020). Advantages, Limitations and Recommendations for online learning during COVID-19 pandemic era. Pakistan Journal of Medical Sciences, 36(COVID19-S4), S27.

Nicola, M., Alsafi, Z., Sohrabi, C., Kerwan, A., Al-Jabir, A., Iosifidis, C., Agha, M., \& Agha, R. (2020). The socio-economic implications of the coronavirus and COVID-19 pandemic: A review. International Journal of Surgery, 78, 185-193

Octaberlina, L. R., \& Muslimin, A. I. (2020). Efl students perspective towards online learning barriers and alternatives using moodle/google classroom during covid-19 pandemic. International Journal of Higher Education, 9(6), 1-9.

Oktavianti, E., Handayanto, S. K., Wartono, W., \& Saniso, E. (2018). Students' scientific explanation in blended physics learning with e-scaffolding. Jurnal Pendidikan IPA Indonesia, 7(2), 181-186. 
Podolefsky, N. S., \& Finkelstein, N. D. (2007). Analogical scaffolding and the learning of abstract ideas in physics: An example from electromagnetic waves. Physical Review Special Topics-Physics Education Research, 3(1), 010109.

Porter, W. W., Graham, C. R., Spring, K. A., \& Welch, K. R. (2014). Blended learning in higher education: Institutional adoption and implementation. Computers \& Education, 75, $185-195$.

Purwanto, A., Pramono, R., Asbari, M., Hyun, C. C., Wijayanti, L. M., \& Putri, R. S. (2020). Studi eksploratif dampak pandemi COVID-19 terhadap proses pembelajaran online di sekolah dasar. EduPsyCouns: Journal of Education, Psychology and Counseling, 2(1), $1-12$.

Rahmawati, R., \& Putri, E. M. I. (2020). Learning From Home dalam Perspektif Persepsi Mahasiswa Era Pandemi Covid-19. Prosiding Seminar Nasional Hardiknas, 1, 17-24.

Santrock, J. W. (2011). Educational psychology. McGraw-Hill.

Saputri, A. A., \& Wilujeng, I. (2017). Developing Physics E-Scaffolding Teaching Media to Increase the Eleventh-Grade Students' Problem Solving Ability and Scientific Attitude. International Journal of Environmental and Science Education, 12(4), 729-745.

Sefriani, R., Sepriana, R., Wijaya, I., \& Radyuli, P. (2021). Blended Learning with Edmodo: The Effectiveness of Statistical Learning during the COVID-19 Pandemic. International Journal of Evaluation and Research in Education, 10(1), 293-299.

Serhan, D. (2020). Transitioning from Face-to-Face to Remote Learning: Students' Attitudes and Perceptions of Using Zoom during COVID-19 Pandemic. International Journal of Technology in Education and Science, 4(4), 335-342.

Setiawan, T. (2018). The Exploration of Using E-Scaffolding in Solving Physics Problem.

Setyosari, H. P. (2016). Metode penelitian pendidikan \& pengembangan. Prenada Media.

Susilawati, S., \& Supriyatno, T. (2020). Online learning through WhatsApp group in improving learning motivation in the era and post pandemic COVID-19. Jurnal Pendidikan: Teori, Penelitian, Dan Pengembangan, 5(6), 852-859.

Tinungki, G. M., \& Nurwahyu, B. (2020). The Implementation of Google Classroom as the ELearning Platform for Teaching Non-Parametric Statistics during COVID-19 Pandemic in Indonesia. International Journal of Advanced Science and Technology, 29(4), 57935803.

Wicaksana, E. (2020). Efektifitas Pembelajaran Menggunakan Moodle Terhadap Motivasi Dan Minat Bakat Peserta Didik Di Tengah Pandemi Covid-19. EduTeach: Jurnal Edukasi dan Teknologi Pembelajaran, 1(2), 117-124.

Wicaksana, E. J., Atmadja, P., Wikanso, W., Putri, L. N., \& Muthia, G. A. (2020). Edmodo as a solution to enhance student learning interest in high school biodiversity during the COVID-19 pandemic. Biosfer: Jurnal Pendidikan Biologi, 13(2), 216-229.

Wintarti, A., Ekawati, R., \& Fiangga, S. (2019). Blended Learning as a Learning Strategy in the Disruptive Era. Journal of Physics: Conference Series, 1387(1), 012127. 